\section{Changes in the bioavailability of iron(III) for microbial reduction along a precipitation gradient}

LEA SAUTER ${ }^{1}$, CHRISTOPHER SCHWERDHELM ${ }^{2}$, TOBY SAMUELS $^{2}$, KRISTINA WITZGALL ${ }^{3}$, FERDINAND HAMPL $^{4}$, CARSTEN W MUELLER ${ }^{5}$, NICOLAS-ANDRES RIVERAS $^{2}$, THOMAS SCHOLTEN ${ }^{2}$, DIRK WAGNER ${ }^{6,7}$, CAROLINA MERINO $^{8,9}$, FRANCISCO MATUS $^{8}$, THOMAS NEUMANN $^{10}$, ANDREAS KAPPLER ${ }^{2}$ AND CASEY BRYCE $^{11}$

${ }^{1}$ Geomicrobiology, Department of Geosciences, University of Tuebingen

${ }^{2}$ University of Tuebingen

${ }^{3}$ Technical University of Munich

${ }^{4}$ Technische Universität Berlin

${ }^{5}$ University of Copenhagen

${ }^{6} \mathrm{GFZ}$ German Research Center for Geoscience

${ }^{7}$ University of Potsdam

${ }^{8}$ Universidad de la Frontera

${ }^{9}$ Center of Plant, Soil Interaction and Natural Resources

Biotechnology Scientific and Technological Bioresource Nucleus (BIOREN)

${ }^{10}$ Department of Applied Geochemistry, Technische Universität Berlin

${ }^{11}$ University of Bristol

Presenting Author: lea.sauter@uni-tuebingen.de

The bioavailability of iron is essential for nearly every living organism on Earth. However, it is not yet clear whether climatic factors, such as precipitation, influence the bioavailability of ferric iron for microorganisms in soils. Fe(III)-reducing bacteria use $\mathrm{Fe}$ (III)-(oxyhydr)oxides as a terminal electron acceptor to gain energy for metabolic purposes. We examined the bioavailability of $\mathrm{Fe}$ (III)-minerals in soils influenced by different precipitation regimes from four regions (between $26^{\circ} \mathrm{S}$ and 38 $\left.{ }^{\circ} \mathrm{S}\right)$ along the Chilean Coastal Cordillera using geochemical and mineralogical analyses, and batch experiments. We found several trends in extracted iron, organic carbon and nitrate within soil depth $(0-20 \mathrm{~cm})$ and latitude and identified differences in the iron mineralogy e.g., more crystalline Fe(III)-oxyhydroxides such as goethite were detected in the hyper arid area. Moreover, we showed in batch experiments that the Fe(III)-reducing bacteria Shewanella oneidensis MR-1 was able to reduce Fe(III)-minerals in soils from areas with a mean annual precipitation (MAP) of $120-1153 \mathrm{~mm}$ when supplied with sufficient lactate as an electron donor, whereas no iron reduction was detected in soils from the hyper arid (MAP: $39 \mathrm{~mm}$ ) area. These results suggest that geochemical conditions influenced by precipitation in soils determine the bioavailability of Fe(III)-minerals below a certain threshold of precipitation.

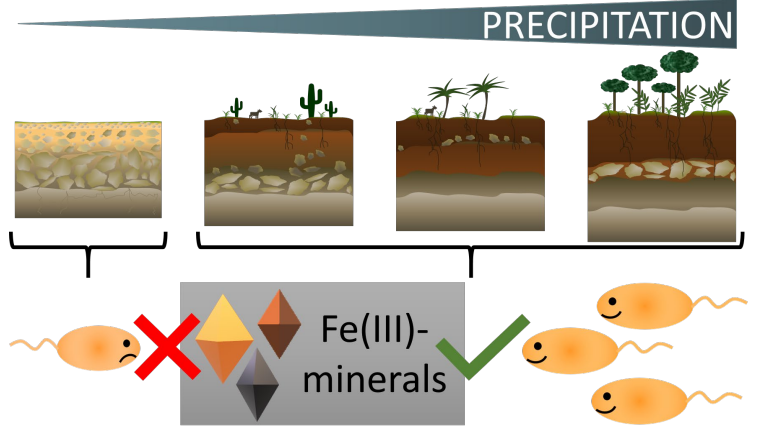

